\title{
Smart City and Human Resource Governance: A Case Study in Banyuwangi
}

\author{
Laila Kholid Alfirdaus ${ }^{1}$, Dzunuwwanus Ghulam Manar ${ }^{2}$, Teguh Yuwono ${ }^{3}$ \\ \{alfirdaus_laila@yahoo.com ${ }^{1}$ \} \\ Universitas Diponegoro, Indonesia ${ }^{1,2,3}$
}

\begin{abstract}
Amongst the scholarly discussions on smart cities, the human resource aspect is almost absent from elaborating. Meanwhile, human resources is a crucial part in the adoption of smart city policy. Moreover, within the context of developing countries, human resources always become an issue given its complex problems due to limited education and relatively low-skilled staff in bureaucracy, including in Asian countries. However, some local governments in these regions are known to succeed in promoting smart city policy. This article discusses human resource governance, despite the complexities the local government faces, in undergoing smart city policy in developing context. This article uses Banyuwangi regency as a case study using qualitative methods and applying interviews and observations as data collection methods. Based on research findings, leadership is the first key to manage human resources, followed by a clear incentive and disincentive policy, equipped with a cultural approach. Banyuwangi experience can be a good lesson for other regencies to learn for promoting innovation and local governance transformation.
\end{abstract}

Keywords: Smart City, Innovation, Human Resource, Governance.

\section{Introduction}

Along with the mission of public service improvement, the adoption of the smart city concept in Indonesian urban planning is rising. Most of the regencies apply Internet-based technologies to enable public service and deliveries easier to reach citizens across geographies in the region. However, it is still unclear how the governance of smart city policy is under the circumstances of bureaucratic complexities that are generally known to have slow performance, lack of motivation, and, somehow, corrupt. This article discusses smart city policy and the governing of human resource in the policy implementation using Banyuwangi regency as a case of study. As we might be aware of, Banyuwangi is known to be one of the regencies that succeeded in improving its service provision within the last decade through the adoption of Internet-based technology until the village government level. It also succeeded in boosting local income up to five folds within five years through the adoption of Internet-based tourism governance. Further impact, Banyuwangi regency's poverty rate went down from 20 percent to 7 percent in five years.

The success of the Banyuwangi government in building its smart city policy did not come in sudden. According to the research finding, the very first foundation is in human resource governance. Under the new leadership of Abdullah Azwar Anas, a decade ago, the governance of Banyuwangi's human resource was started with a competence-based approach, 
in which the right people are designed to sit in the right place. This policy implementation is since the recruitment phase to the regular official rotation. Realizing the urgency of having quality human resources, the government recruited ten university graduates from IT and ten from accounting disciplines in the first years of Regent Anas in 2011. The IT graduates were supposed to support the government to adopt Internet-based technology as the foundation for smart city building. In contrast, accounting graduates were supposed to support government administration and accountability improvement.

In the second phase, the government implements a stick and carrot system, in which incentive and disincentive approach play as a tool to encourage government apparatus' performance [1]. In this case, the staff is proportionally rewarded (and also punished) according to their performance level to maintain the endurance of smart city policy. Finally, in order to avoid tension within bureaucracy's officers, the government applies an incremental/gradual approach in staff promotion, in which career improvement for junior staff, who have excellent performance, is designed not to jump over their seniors' one. As a result, despite resistance in the first phases, nowadays, Banyuwangi's human resource governance is more established, and its smart city's policy endurance looks sounder as compared to the other regencies/cities in Indonesia.

\section{Theoretical Framework}

\subsection{Smart City, Human Resource and Developing Governance}

\subsubsection{Defining Smart City}

The rise of the smart city concept cannot be inseparable from the public service improvement agenda. A smart city means bettering off service provision through the use of the Internet and digital technology to ease coordination (among stakeholders), connectedness between actors, and efficiency in delivering services. As such, the smart city idea deeply relates to knowledge management and human resources.

By definition, a smart city refers to technology. Some other scholars refer to citizenship. The others refer to social capital and technology [2]. Amongst the ideas, what Dameri [3] explains as the smart city might help us understand better about what smart city is. As Dameri [3] argues, "the smarter city is the one that has, the larger intellectual capital and can use its knowledge to choose the better solutions for the further development of the city quality. Investments in cultural initiatives are therefore welcome, but especially the city should use its awareness to promote sustainable development, balanced economic growth, and environmental quality in the urban areas" [4]. Dealing with this, there at least eight manifestations of smart city implementation that include: smart governance and smart education, smart citizen, smart energy; smart technology; smart infrastructure; smart mobility; smart building, and smart healthcare [5].

By this definition, it becomes clear that what needs to underline in the smart cities is knowledge and technology used to support sustainable development, economic growth, and the preserved environment in city areas. Therefore, human resources as the locus of knowledge posit a crucial role in designing and promoting the smart city. Human resource is the key. 


\subsubsection{Human Resource Governance in the Public Sector}

Some criticisms see human resource governance in the public sector is not adequate. Problems of human resources in the public sector are seen too fat, inefficient, having slow performance, and sometimes personal, including handling public services that should be professional [6]. Along with the rapid change in society, bureaucracy is pushed to change its culture, first of all, by changing its human resources. Transforming human resource governance, as such, becomes unavoidable [7]. Of course, this would not be going smoothly. Challenges and barriers are a particular issue to manage. The rapid change in society can be either seen as a challenge to perform better or otherwise as a burden that bureaucracy chooses to leave (nor responsive and keep working with a business as usual approach).

As Daly [8] identifies, human resource governance aims at supporting the achievement of vision, mission, goals, and values of the organization. Daly [8] identifies, there are at least six foundations to generate useful and qualified human resources. They are responsiveness to the public's will, social equity, mission-driven focus, skills-based competency in employment practices, professional human resource competency, and Ethically based organizational culture.

At this point, leadership becomes of the keys to make sure that human resources can function adequately in bureaucracy. Managing hundreds, even thousands of individuals in the public sector with various kinds of capacity, capability, motivation, and personal interests in order to support him/her achieve his/her missions need a strategy. A leader needs the ability to differentiate the kind of human resource in bureaucracy. As Daly [8] identifies, there are three different levels of human resources that ideally support one another in achieving the organization's vision and mission. They include:

a) Strategic HR management. This includes leaders and their surrounding stakeholders. In regencies, this is held by regent. By sitting in a strategic position, regent's main task is to make sure that available human resource in their organization is well-oriented to support them achieve the vision, mission, and organization's goal.

b) Tactical HR management. This level has a position between strategic and operational ones. Tactical human resources have a task for interpreting the direction of a leader to be operationalized on a lower level. Similarly, the tactical human resource also connects practical things to be steps to achieve organizational goals.

c) Operational HR management. Operational human resource has a task to operate the daily administration of the organization. The nature of operational human resource management is labor-intensive and functions to do what strategic level human resource conducting and tactical level orienting.

Indeed, the categorization does not mean that one and another are separated. Strategic level human resources sometimes need to go down to make sure that the designed policy is easy to practice and is in line with the organization's vision and mission.

\subsubsection{Human Resource in Smart City Policy}

While human resource issues in the public sector can be so problematic, as discussed by scholars, what is they mobilized to support smart city policy? As widely known, smart city applies high technology in delivering public service and in operating daily administrative works. However, before the periods where staff are accustomed to technology and can be disseminated in all service units, starting, and transition era must be hard. Moreover, in developing countries like Indonesia, where people bound with collective culture and 
traditional ways of working, technology can be so intimidating. Therefore, planning and preparation are essential. In addition to the lack of education, developing countries are also usually left behind in technology and information adoption and creation that can support public sector performance.

Despite challenges and barriers in governing human resources in developing countries, interestingly, some local leaders succeed in creating innovation, as in smart city policy [9]. Indeed, there are resistance, refusal, and somehow rebellion from old-generation bureaucrats for seeing the breakthrough as burdening and adding workloads. Those leaders can keep focused on what they are doing. Moreover, smart city policy can only succeed once supported by smart human resources. As Albert dan Bol'ivar [10] argues, those who focus on human resources believe that smart people are the key to succeeding innovation through smart city policy. Smart people, as Dameri [3] suggests fulfilling six criteria as the following:

a) Level of qualification.

b) Affinity to lifelong learning.

c) The social and ethnic plurality.

d) Flexibility.

e) Creativity.

f) Cosmopolitanism/open-mindedness.

g) Participation in public life.

The crucial point to discuss is, who do we mean by smart people in the smart city? First of all, is the local government (city or regency government). The representation of local government that becomes the key, in this case, is mayor or regent that posit top executive in the local government body. Mayor or regent mobilizes city or regency's resources. They symbolize the government as a whole. The second is a citizen (as a user of public service). Smart citizens do not only become the determining factor of a smart city but can also be the result of a smart city.

The next point to identify is how limited human resources can be developed in order to achieve the goal of smart city policy? As Albert dan Bol'ivar [10] describes, there are two approaches to apply to make a dream of a smart city comes true. The first is a transformative approach. In this approach, the local government heads take a speedy step to implement smart city policy. The government staff is forced to perform fast and adjust to their pace of work. The risk of this approach is that political support may decrease slowly, but the result can be quickly seen. The second is incremental, in which the implementation of a smart city is done gradually adjusting with the local government's capacity. In this case, political resistance might be able to minimize, but the goal might be longer achieved. However, as the terms for being in the executive body is not long lasted, the second approach is prone to uncertainties.

The most important question dealing with this is how to apply the transformative approach that is politically more conducive? Some regencies in Indonesia apply a clear reward and punishment, as in Yogyakarta and Banyuwangi. By using this approach, bureaucratic staffs are encouraged to perform well. So far, the two regions succeed in reforming the bureaucracy and gain optimal support from the staff to create a smart city, despite some weaknesses that still need for improvement shortly. 


\section{Result and Discussion}

\subsection{Human Resource Governance in Smart City Promotion: The Case of Banyuwangi Regency}

When Abdullah Azwar Anas firstly won the recent election in 2010, Banyuwangi was among the poorest regencies in East Java. Indeed, Anas was ware of his regency's problem. However, instead of imposing particular programs for eradicating poverty, what regent Anas first doing was to reform the government,

First of all, Anas's priority was to reform government officers' recruitment. While the other regencies in 2010 were widely known to "sell" seats in the recruitment (see the case of Tuban, Rembang, and many other regencies or cities), what Anas did is the reverse. He recruited government officers, who were among the best university graduates. His priority was to recruit those who have skill in Information and Technology and Accounting. Mastering IT for Anas is a clear need for local governments to support the government's adjustment to the rapid change in society. Meanwhile, reliable accounting staffs is to support Banyuwangi regency to fulfill the demands for accountability and transparency in government administration and finance. Therefore, IT and accounting graduates were put in the mostwanted position in government officers' recruitment at the moment.

Later on, it is proven that Banyuwangi is then widely known as among the few regencies in Indonesia that is aware of the Internet and technology in supporting public service. It even widens the use of the Internet to advertise its tourism, so it becomes one of the new risingtourism destinations in Indonesia. Also, Banyuwangi is known for years for its best performance in government administration. It is among the best local governments in terms of accountability and transparency. For years, its annual performance reports were awarded AA (double-A) status indicating that most local government elements work beyond expectation, either in terms of achievement, accountability, and transparency. The progress in tourism visits and the improvement of government service, slowly but sure, has lifted out Banyuwangi from the poverty trap.

Anas's first move in government officers' recruitment, as discussed above, indicated Anas's awareness that having quality human resources is key to better off government performance. This is what missed in the other regencies. For some politicians, the recruitment period is seen as a period to "harvest" (by allowing bribery to practice among applicants). At the same time, for Anas, it is time for spreading seed and planting. Nowadays, Anas and Banyuwangi harvest the result, namely the well-organized, well-performing government, and the rising star in a tourism destination.

Indeed, recruitment is not the only key to success. In government officers' promotion, Anas also apply the professional standard. This means those who work professionally will gain promotion gradually. However, Anas does not neglect the possibility of tension among bureaucratic staffs in terms promotion. Therefore, Anas applies gradual promotion, in which the older gain the promotion first than the younger staffs. Of course, it is not only because the staff is old then they are promoted. Anas remains to push the old staff to be digitally literate to support smart kampung as Anas's vision. Above all, for Anas, maintaining the favorable circumstances in bureaucracy is essential. Otherwise, Anas will find difficulties in conducting them doing their daily tasks.

Also, Anas applies incentives and disincentives in maintaining the performance rhythm of his staff. By giving incentives, Anas means that the staff will feel more appreciated towards what they have done. With the incentive, people also get more enthusiastic about improving 
their performance. Similarly, by applying disincentive, Anas means to let the staffs know that there is no gain if there is no pain. Anas wanted to make sure that the government's money is not wasted for those who do not perform well in daily activities.

\section{Conclusion}

From the discussion above, we can see that human resource governance is the crucial Banyuwangi regency to support the achievement of its goal. Banyuwangi regent, namely Abdullah Azwar Anas, exactly knows what and how to start to develop Banyuwangi, namely through its human resource. Starting from recruitment, improvement in human resource is followed with professionality based promoted and equipped with incentive and disincentive approach to control bureaucratic staffs' performance. There are still many things to do in Banyuwangi. However, regent Anas has established the foundation for his predecessor to continue the Banyuwangi dream as a prosper regency.

\section{References}

[1] L. G. Anthopoulos, Understanding Smart Cities: A tool for smart government or an industrial trick?, vol. 22. Springer, 2017.

[2] V. Albino, U. Berardi, and R. M. Dangelico, "Smart cities: Definitions, dimensions, performance, and initiatives," J. urban Technol., vol. 22, no. 1, pp. 3-21, 2015.

[3] R. P. Dameri, "Smart city implementation Creating Economic and Public Value in Innovative Urban Systems," Prog. IS; Springer Genoa, Italy, 2017.

[4] Y. M. Adnan, H. Hamzah, M. M. Dali, M. N. Daud, and A. Alias, "An initiatives-based framework for assessing smart city," Plan. MALAYSIA, vol. 14, no. 5, 2016.

[5] S. Sambrook and J. Stewart, "HRD in health and social care," in Human Resource Development in the Public Sector, Routledge, 2007, pp. 25-36.

[6] J. D. Grant and H. Toch, "Harnessing Human Resources in the Public Sector," Econ. Ind. Democr., vol. 5, no. 2, pp. 227-248, 1984.

[7] M. P. Rodríguez-Bolívar, Transforming city governments for successful smart cities. Springer, 2015.

[8] J. L. Daly, Human resource management. Routledge, 2012.

[9] S. Borrás and C. Edquist, "The choice of innovation policy instruments," Technol. Forecast. Soc. Change, vol. 80, no. 8, pp. 1513-1522, 2013.

[10] A. Meijer and M. P. R. Bolívar, "Governing the smart city: a review of the literature on smart urban governance,” Int. Rev. Adm. Sci., vol. 82, no. 2, pp. 392-408, 2016. 